\title{
Interleukin-1 $\beta$ mediates high glucose induced phenotypic transition in human aortic endothelial cells
}

\author{
Dong-Dong Zhu, Ri-Ning Tang ${ }^{\dagger}$, Lin-Li Lv, Yi Wen, Hong Liu, Xiao-Liang Zhang, Kun-Ling Ma and Bi-Cheng Liu
}

\begin{abstract}
Background: Previous studies have shown that high glucose (HG) induced endothelial cell (EC) damage via a phenotypic transition of EC. There is increasing evidence suggesting the role of inflammatory cytokines in mediated HG-induced EC damage. However, little is known about the potential role of interleukin-1 $\beta$ (IL-1 $\beta$ ) in the process. The aim of present study was to investigate whether IL-1 $\beta$ mediated HG-induced phenotypic transition in human aortic endothelial cells (HAECs) and to determine the possible underlying mechanism.
\end{abstract}

Methods: Primary HAECs were exposed to normal glucose (NG, $5.5 \mathrm{nM}$ ), high glucose (HG,30 nM), IL-1 1 (10 ng/ $\mathrm{ml}), \mathrm{HG}+\mathrm{IL}-1 \beta(10 \mathrm{ng} / \mathrm{ml})$ and $\mathrm{HG}+$ anti-IL-1 $\beta$ antibodies $(1000 \mathrm{ng} / \mathrm{ml})$ or HG + IL-1 $\beta$ small interfering RNA (siRNA). Pathological changes were investigated using confocal microscopy and electron microscopy. Confocal microscopy was performed to detect the co-expression of CD31 and fibroblast specific protein 1 (FSP1). To study the effect of protein kinase $C-\beta$ (PKC $\beta$ ) activation on IL-1 $\beta$ in HAECS, HAECs were stimulated with 30 nM PMA (PKC $\beta$ activator) and $0.3 \mu \mathrm{M}$ PKC $\beta$ inhibition (LY317615) for $48 \mathrm{~h}$ in the NG or HG group. The expressions of PKC $\beta$ and IL-1 $\beta$ were detected by RT-PCR and Western blot. And the concentration of IL-1 $\beta$ in the supernatant of HAECs was measured by ELISA. The expressions of FSP1, a-SMA and CD31 were detected by Western blot.

Results: It was shown that the $\mathrm{HG}$ resulted in significant increase in the expressions of PKC $\beta$ and IL-1 $\beta$ in dose-and time-dependent manners. The HG or exogenous IL-1 $\beta$ alone inhibited the expression of CD31 and markly increased the expressions of FSP1 and a-SMA. Furthermore, we observed that the HG and IL-1 $\beta$ synergistically increased FSP1 and a-SMA expressions compared with the HG or IL-1 $\beta$ alone group $(P<0.05)$. Confocal microscopy revealed a colocalization of CD31 and FSP1 and that some cells acquired spindle-shaped morphologies and a loss of CD31 staining. Electron microscopy showed that the HG resulted in the increased microfilamentation and a roughened endoplasmic reticulum structure in the cytoplasm. However, the changes above were attenuated by the intervention of anti-IL-1 $\beta$ antibodies or IL-1 $\beta$ siRNA $(P<0.05)$. In addition, the PMA induced the expressions of PKC $\beta$ and IL-1 $\beta$ in HAECs. The PKC $\beta$ activation may mediate the effect of the HG on IL-1 $\beta$ production, which could be attenuated by the PKC $\beta$ selective inhibitor $(L Y 317615)(P<0.05)$.

Conclusions: Our findings suggested that HG-induced phenotypic transition of HAECs might require IL- $\beta$ activation via the PKC $\beta$ pathway.

Keywords: High glucose, Endothelial damage, Interleukin-1 $\beta$, PKC

\section{Background}

Diabetes is a growing epidemic worldwide. Vascular complications of diabetes are the most serious manifestations

\footnotetext{
*Correspondence: liubc64@163.com

${ }^{\dagger} \mathrm{Ri}$-Ning Tang is the co-first author

Institute of Nephrology, Zhongda Hospital, Southeast University School

of Medicine, Nanjing 210009, China
}

of the disease. Endothelial cell (EC) damage is a critical and initiating factor in the development of diabetic vascular complications [1-3]. Emerging evidence has suggested that diabetes was one of the inflammatory diseases and high glucose (HG) induced inflammation is involved in the onset and progression of EC damage [4]. 
Furthermore, previous studies have also shown that the inflammatory cytokines promote the EC damage [5-7].

In particular, interleukin-1 $\beta$ (IL-1 $\beta$ ) has been involved in the pathogenesis of diabetes [8-10]. Accordingly, IL-1 $\beta$ antagonist has been proposed as a promising therapeutic approach to diabetes $[11,12]$. Moreover, further studies elucidated the link between IL- $1 \beta$ and the development of cardiovascular complications [13, 14]. Recently, Vallejo et al. [15] indicated that IL-1 $\beta$ correlated with EC damage in a short-term model of type 1 diabetes. Together, these findings indicated that IL- $1 \beta$ may play a key role to EC damage in diabetes. However, the underlying mechanism remains to be not understood.

Interestingly, multiple studies reported that IL-1 $\beta$ can initiate the transition of EC to mesenchymal cell [16-19]. This transition process is called endothelial to mesenchymal transition (EndMT), characterized by the loss of cell-cell adhesion, the changes in cell polarity, the reduction of EC markers, such as CD31, and the overexpression of mesenchymal cell markers, such as $\alpha$-smooth muscle actin ( $\alpha$-SMA) and fibroblast-specific protein1 (FSP1). More recent studies demonstrated that EndMT contributed to EC damage [2023]. Additionally, our previous studies also proved that HG could induce EC damage via EndMT [24, 25].

Therefore, the aim of this study was to investigate whether IL- $1 \beta$ mediates HG-induced phenotypic transition in human aortic endothelial cells (HAECs) and the underlying mechanism of IL- $1 \beta$ regulation.

\section{Methods}

\section{Cell culture and reagents}

Primary HAECs were purchased from Sciencell Research Laboratories (USA) and cultured as previously described. Briefly, cells were grown in endothelial culture medium (No. 1001, Sciencell) containing $5 \%$ fetal bovine serum (FBS) (No. 0025), $1 \%$ endothelial cell growth supplement (No. 1052) and $1 \%$ penicillin/streptomycin solution (No. 0503) in $5 \% \mathrm{CO} 2$ at $37^{\circ} \mathrm{C}$. Passage 2-4 HAECs were expanded in monolayers in flasks or dishes. At approximately $80 \%$ confluence, the culture medium was changed to a serum-free solution for $24 \mathrm{~h}$ prior to their use in all of the experiments. To examine the effect of high glucose on IL- $1 \beta$ secretion and phenotypic transition in HAECs, HAECs were treated with normal glucose (NG: $5.5 \mathrm{mM}), 15 \mathrm{mM}$ D-glucose, $\mathrm{HG}$ (30 mM D-glucose) and MN (5.5 mM NG $+24.5 \mathrm{mM}$ mannitol) for $48 \mathrm{~h}$. And to identify the effect of IL- $1 \beta$ on phenotypic transition in HAECs, the cells were cultured in the presence of
IL-1 $\beta$ (Peprotech, $10 \mathrm{ng} / \mathrm{ml}$ ), anti-IL-1 $\beta$ antibodies(R\&D System, $1000 \mathrm{ng} / \mathrm{ml}$ )or IL-1 $\beta$ siRNA (Santa Cruz, sc-39615 IL-11 $\beta$ siRNA(h); sc-45064 siRNA Reagent System) for $48 \mathrm{~h}$. To examine the effect of $\mathrm{PKC} \beta$ activation on IL-1 $\beta$ production, HAECs were stimulated with $30 \mathrm{nM}$ phorbol 12-myristate 13-acetate (PMA, Sigma) [10] in NG group, and were incubated with HG/NG containing the PKC $\beta$ selective inhibitor LY317615 (Selleck, $0.3 \mathrm{uM}$ ).

\section{Enzyme linked immuno-sorbent assay (ELISA)}

The cell supernatant was collected, and the IL- $1 \beta$ production was measured using a commercially available ELISA kit (R\&D System) according to the protocol described by the manufacturer.

\section{Real-time PCR}

Total RNA was extracted using RNAiso Plus according to the manufacturer's directions (TAKARA, China). RNA concentration and purity were confirmed with a Nanodrop 2000 (Thermo, USA). Samples with a relative absorbance ratio at 260/280 between 1.8 and 2.0 were used. All of the RNA samples were reverse transcribed (Applied Biosystems, USA). Quantification of specific mRNAs was performed using an ABI Prism 7300 Sequence Detection System (Applied Biosystems, USA) with the SYBR Green Real-time PCR Kit (TAKARA, China). The following oligonucleotide primer sequences were used: IL-1 $\beta$ :forward $5^{\prime}$,T G A A A T G A T G G C T T A T T A C A G T G G $3^{\prime}$, reverse $5^{\prime}$, G T A G T G G T G G T C G G A G A T T C G T A G 3'; PKC $\beta$ :forward $5^{\prime}, \mathrm{G}$ A A A T T T G A G A G G G C C A A G A $3^{\prime}$, reverse $5^{\prime}, \mathrm{C}$ C C A G C A C C A T T A G G A A G T $\mathrm{T} 3^{\prime}$, (designedand synthesized by Generay, China). Relative mRNA amounts were normalised to GAPDH and calculated using the standard curve method. In brief, the pre-PCR product of each gene was used as the standard. The standard curve was established with a tenfold serial dilution of the product and was included in all PCR runs. The ratio of targetgene housekeeping was used to evaluate the expression level of each gene. Control consisting of $\mathrm{dd} H 2 \mathrm{O}$ were negative in all runs.

\section{Western blot analysis}

Total cellular protein was extracted to evaluate the levels of CD31, FSP1, $\alpha$-SMA, IL- $1 \beta$ and PKC $\beta$. Equal amounts of protein obtained from each lysate were electrophoresed in a 4-20\% SDS-polyacrylamide gel and transferred onto nitrocellulose membranes (Pall, USA) 
by electroblotting. The blots were incubated overnight with primary antibodies against CD31 (sc-1506, Santa Cruz, CA), FSP1 (ab-27957, Abcam), a-SMA (ab-5694, Abcam), IL-1 $\beta$ (MAB601, R\&D System) and PKC $\beta$ (GTX113252, GeneTex) followed by horseradish peroxidase-labelled secondary IgG (Santa Cruz). Signals were detected using an advanced ECL system (GE Healthcare, UK). $\beta$-actin was used as the internal control.

\section{Confocal microscopy}

HAECs grown on coverslips were fixed in $4 \%$ paraformaldehyde and permeabilised with $0.5 \%$ Trition-X100. After blocking with $10 \%$ bovine serum albumin (BSA) in phosphate-buffered saline for $1 \mathrm{~h}$ at room temperature, they were incubated with primary antibodies against CD31 (sc1506), FSP1 (ab-27957) at $4{ }^{\circ} \mathrm{C}$ overnight. After incubating with secondary antibodies for $1 \mathrm{~h}$ at room temperature in the dark, the images were captured using a laser scanning confocal microscope (LSM 510 META, Zeiss, Germany).

\section{Transmission electron microscopy}

Cells were fixed in $2.5 \%$ glutaraldehyde buffer ( $\mathrm{pH} 7.4$ ). Transmission electron microscopy (TEM) was performed according to a routine fixation and embedding procedure. Thin sections were cut on a microtome, placed on copper grids, stained with uranyl acetate and lead citrate, and examined using a transmission electron microscope (JEM-1010, JEOL, Japan).

\section{Statistical analysis}

Data were analysed by one-way analysis of variance (ANOVA) using SPSS 16.0 software and were expressed as the mean \pm standard deviation (SD). The results of the data analysis were considered to be significant at $P<0.05$.

\section{Results}

\section{HG upregulates IL- $1 \beta$ expression in HAECs}

To demonstrate that enhanced IL-1 $\beta$ expression depended on the concentration and duration of HG exposure, we incubated HAECs in a media that contained $5.5,15$, or $30 \mathrm{mM}$ glucose for $48 \mathrm{~h}$. Mannitol was added to the control cell incubation media to equalize osmolarity. As determined by RT-PCR and ELISA, mRNA and protein expressions of IL- $1 \beta$ increased in response to HG exposure in a dose- and time-dependent manner (Fig. 1).
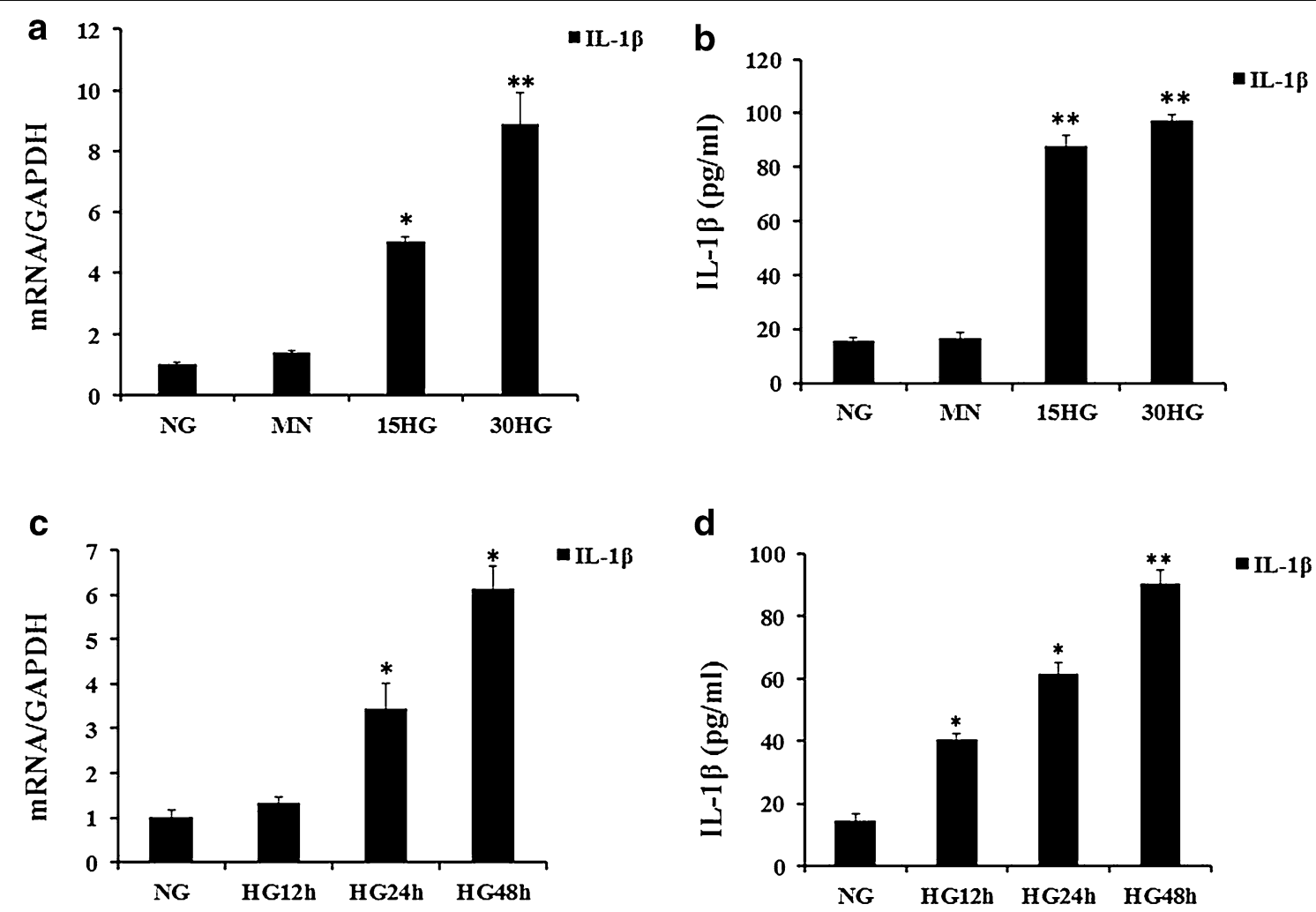

Fig. 1 Effect of high glucose on IL-1 $\beta$ mRNA and protein expression in HAECs. a, b HAECs were incubated for $48 \mathrm{~h}$ with increasing concentrations of glucose $(5.5,15,30 \mathrm{mM})$. Mannitol was used as a control for hyperosmolarity. c, $\mathbf{d}$ HAECs were grown in a $30 \mathrm{mM}$ glucose medium for 12-48 $\mathrm{h}$. $\mathrm{IL}-1 \beta$ protein level was measured in the supernatant using ELISA and IL-1 $\beta$ mRNA level was assayed by quantitative RT-PCR. The data are expressed as the mean \pm SD. Experiments were repeated at least three times. NG normal glucose (5.5 mM), HG high glucose (30 mM), MN $5.5 \mathrm{mM}$ glucose $+24.5 \mathrm{mM}$ mannitol. ${ }^{*} P<0.05$ vs. $\mathrm{MN}$ or NG, ${ }^{* *} P<0.01$ vs. MN or NG 
PKC $\beta$ contributes to HG-induced IL-1 $\beta$ production in HAECs As shown in Fig. 2, HG has a similar effect on PKC $\beta$ expression in addition to IL- $1 \beta$ production. Next, to gain further insight into the mechanisms of IL-1 $\beta$ production in HAECs exposure to HG, we examined PKC $\beta$ and IL-1 $\beta$ expressions in the cells treated with PMA (PKC $\beta$ activator, $30 \mathrm{nM}$ ) or LY317615 (PKC $\beta$ selective inhibitor, $0.3 \mu \mathrm{M})$. We observed that stimulation of HAECs with PMA led to a significant up-regulation of IL-1 $\beta$ protein, accompanying by elevated PKC $\beta$ level, and treatment with LY317615 could inhibit the effect of HG on IL-1 $\beta$ (Fig. 3).

HG and IL-1 $\beta$ alone or in combination resulted in the phenotypic transition in HAECs

We next assessed if exogenous IL-1 $\beta$ or HG could induce the phenotypic transition in HAECs in a distinctive or synergistic manner. As our previous experiments demonstrated, the protein expression of FSP1 and $\alpha$-SMA were progressively up-regulated, whereas the expression of CD31, an EC marker, was down-regulated in the HAECs, which were incubated with HG (30 mM) for 48 h (Fig. $4 \mathrm{a}-\mathrm{d}$ ). Simultaneously, a similar effect was shown in the cells treated with exogenous IL-1 $\beta$ (10 ng/ml). Remarkably, the protein expressions of FSP1 and $\alpha$-SMA strongly increased, while CD31 expression reduced (Fig. 4e-h). We also observed the localization of CD31 and FSP1 in HAECs under confocal microscopy. As shown in Fig. 5a-d, HAECs treated with $10 \mathrm{ng} / \mathrm{mL}$ IL- $1 \beta$ or HG $(30 \mathrm{mM})$ for $48 \mathrm{~h}$ acquired FSP1 staining and lost CD31 staining compared to the control cells.
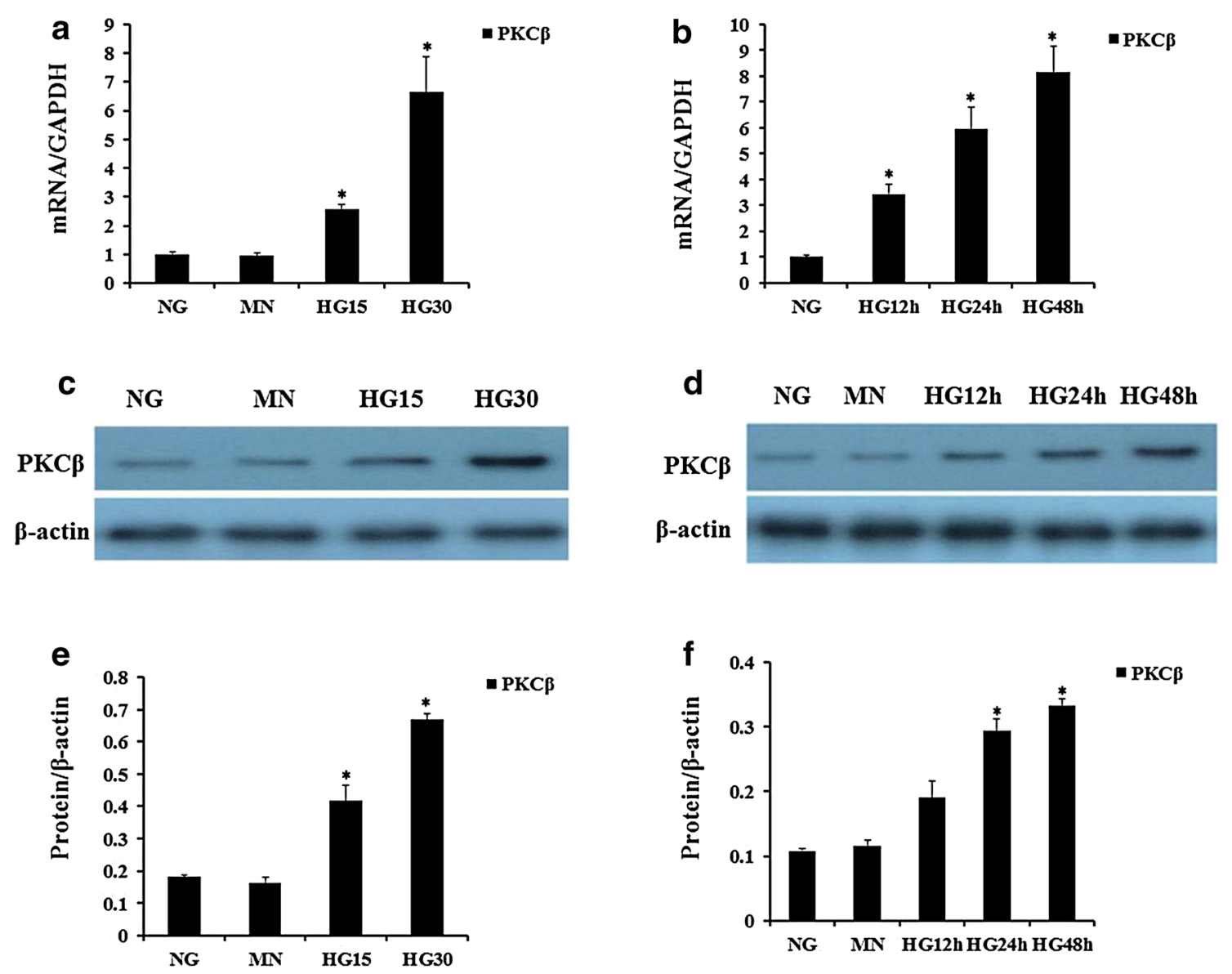

Fig. 2 Effects of high glucose on PKC $\beta$ mRNA and protein expression in HAECs. a, c-e HAECs were incubated for $48 \mathrm{~h}$ with increasing concentrations of glucose $(5.5,15,30 \mathrm{mM})$. Mannitol was used as a control for hyperosmolarity. b. $\mathbf{d}-\mathbf{f}$ HAECs were grown in a $30 \mathrm{mM}$ glucose medium for 12-48 h. PKC $\beta$ mRNA level $(\mathbf{a}, \mathbf{b})$ was assayed by quantitative RT-PCR. Representative western blots $(\mathbf{c}, \mathbf{d})$ and quantitative determinations of PKC $\beta$ protein levels $(\mathbf{e}, \mathbf{f})$ are presented expressed as the mean \pm SD. Experiments were repeated at least three times. NG normal glucose (5.5 mM), HG high glucose $30 \mathrm{mM}$ ), MN $5.5 \mathrm{mM}$ glucose $+24.5 \mathrm{mM}$ mannitol. ${ }^{*} P<0.05 \mathrm{vs}$. MN or NG 

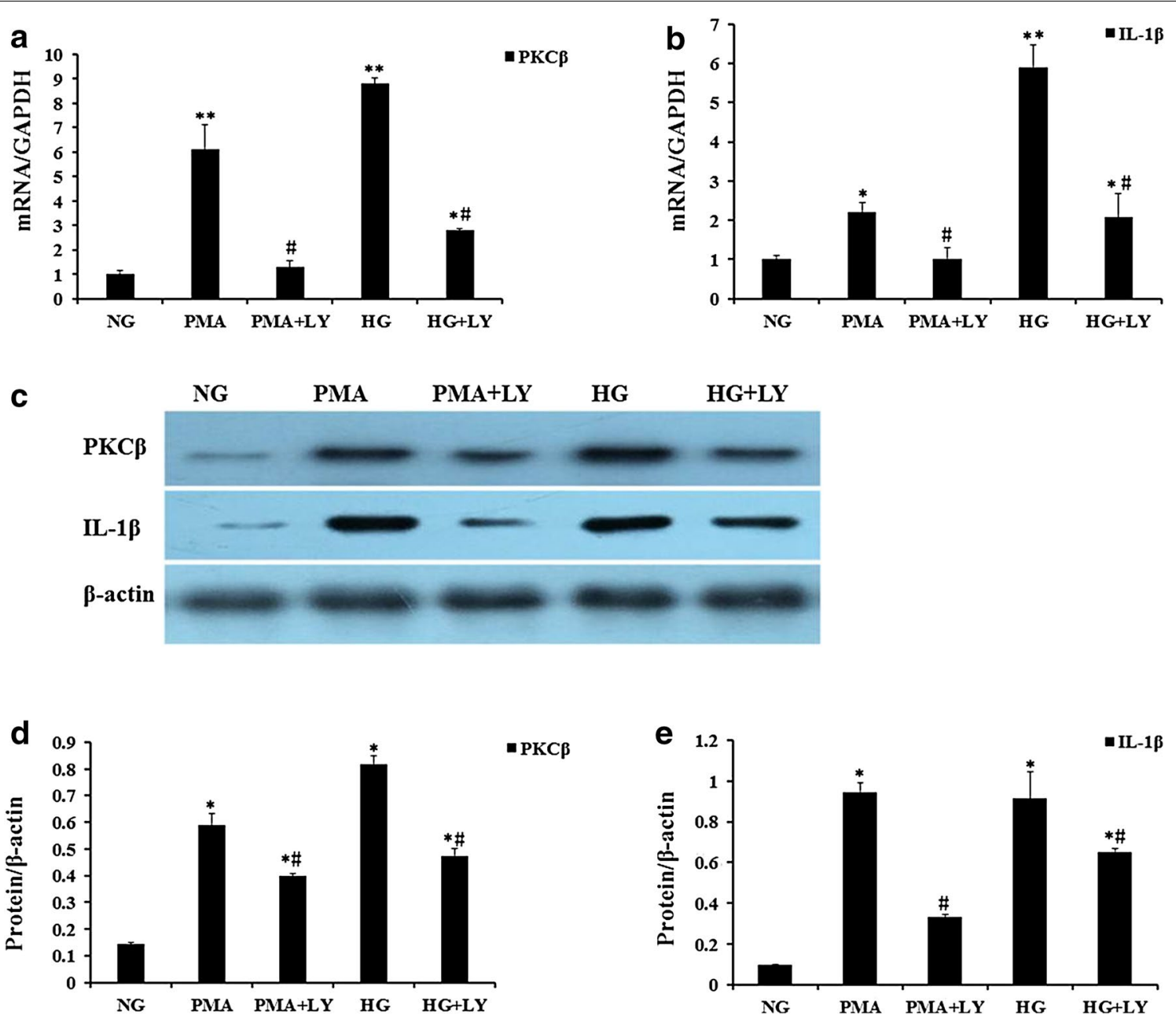

Fig. 3 Effects of PKC $\beta$ on high glucose induced IL-1 $\beta$ up-regulation. Confluent cultures of HAECs were exposed to NG, HG, PMA ( 30 nM) and HG in the presence of the selective PKC $\beta$ inhibitors (LY317615, $0.3 \mu \mathrm{M})$ for $48 \mathrm{~h}$. Real-time PCR analyses showed mRNA expression of PKC $\beta$ and IL-1 $\beta(\mathbf{a}, \mathbf{b})$. Representative western blots ( $\mathbf{c}$ ) and quantitative determinations of PKC $\beta$ and IL-1 $\beta(\mathbf{d}, \mathbf{e})$ are presented. The data are expressed as the mean \pm SD. Experiments were repeated at least three times. NG normal glucose (5.5 mM), HG high glucose (30 mM), PMA (30 nM): phorbol 12-myristate13acetate; LY (0.3 uM): LY317615; ${ }^{*} P<0.05$ vs.NG, ${ }^{* *} P<0.01$ vs. NG, ${ }^{\#} P<0.05$ vs. HG or PMA

\section{Blocking IL-1 $\beta$ inhibited HG-induced phenotypic transition in HAECs}

We further evaluated the influence of IL- $1 \beta$ on the markers related with the phenotypic transition in HAECs. As a classic antagonist, anti-IL-1 $\beta$ antibodies were used to block IL-1 $\beta$ pathway in vitro. As shown in Fig. 6 a-f, the treatment of anti-IL-1 $\beta$ antibodies largely prevented FSP1, $\alpha$-SMA and IL-1 $\beta$ expression in the protein levels and improved CD31 expression. Consistently, the treatment of IL-1 $\beta$ siRNA again suggested that the inhibition of IL-1 $\beta$ prevented HG-triggered mesenchymal transition of HAECs (Fig. 6a1-f1).

\section{Neutralizing IL-1 $\beta$ improved pathological changes} in HAECs

Based on confocal microscopic analysis, normal ECs monolayers displayed a cobble stone morphology (Fig. 7a). In our study, the HAECs, which were exposed to HG for $48 \mathrm{~h}$, exhibited profound changes with cells becoming elongated and spindle-shaped and lost cobblestone morphology. And we performed labelling experiments using anti-CD31 (green) and anti-FSP1 (red, also termed S100A4) antibodies. An analysis of FSP1/CD31 double labelling revealed that some cells acquired FSP1 staining and lost CD31 staining (Fig. 7b, white arrow 


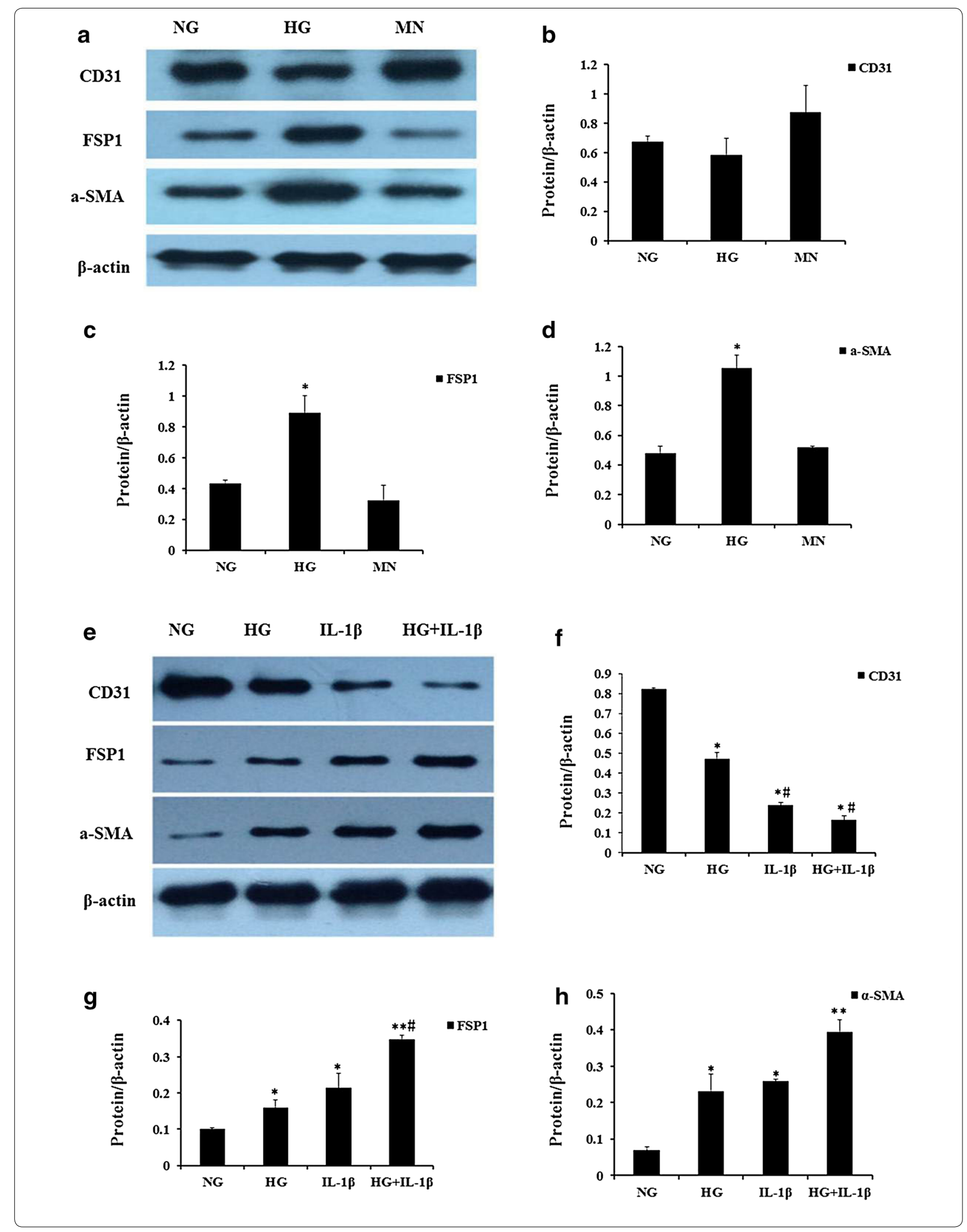


(See figure on previous page)

Fig. 4 Effect of high glucose and IL-1 $\beta$ alone or in combination on the protein expressions of CD31, FSP1 and a-SMA in HAECS. a-d HAECs were incubated for $48 \mathrm{~h}$ with NG and HG. Mannitol was used as a control for hyperosmolarity. Representative western blots (a) and quantitative determinations of CD31, FSP1 and a-SMA protein levels (b-d) are presented. e-h HAECs were treated for $48 \mathrm{~h}$ with NG, HG, IL-1 $\beta$ ( $10 \mathrm{ng} / \mathrm{ml}$ )and HG in the presence of the $\mathrm{IL}-1 \beta(10 \mathrm{ng} / \mathrm{ml})$. Representative western blots (E) and quantitative determinations of CD31, FSP1 and a-SMA protein levels (f-h) are presented. The data are expressed as the mean \pm SD. Experiments were repeated at least three times. NG normal glucose (5.5 mM), HG high glucose (30 mM), MN $5.5 \mathrm{mM}$ glucose + $24.5 \mathrm{mM}$ mannitol, IL-1 $\beta(10 \mathrm{ng} / \mathrm{ml}), \mathrm{HG}+\mathrm{IL}-1 \beta$ : high glucose $(30 \mathrm{mM})+\mathrm{IL}-1 \beta(10 \mathrm{ng} / \mathrm{ml}) * P<0.05 \mathrm{vs}$. MN or NG, ${ }^{* *} P<0.01$ vs. NG, ${ }^{\#} P<0.05$ vs. HG
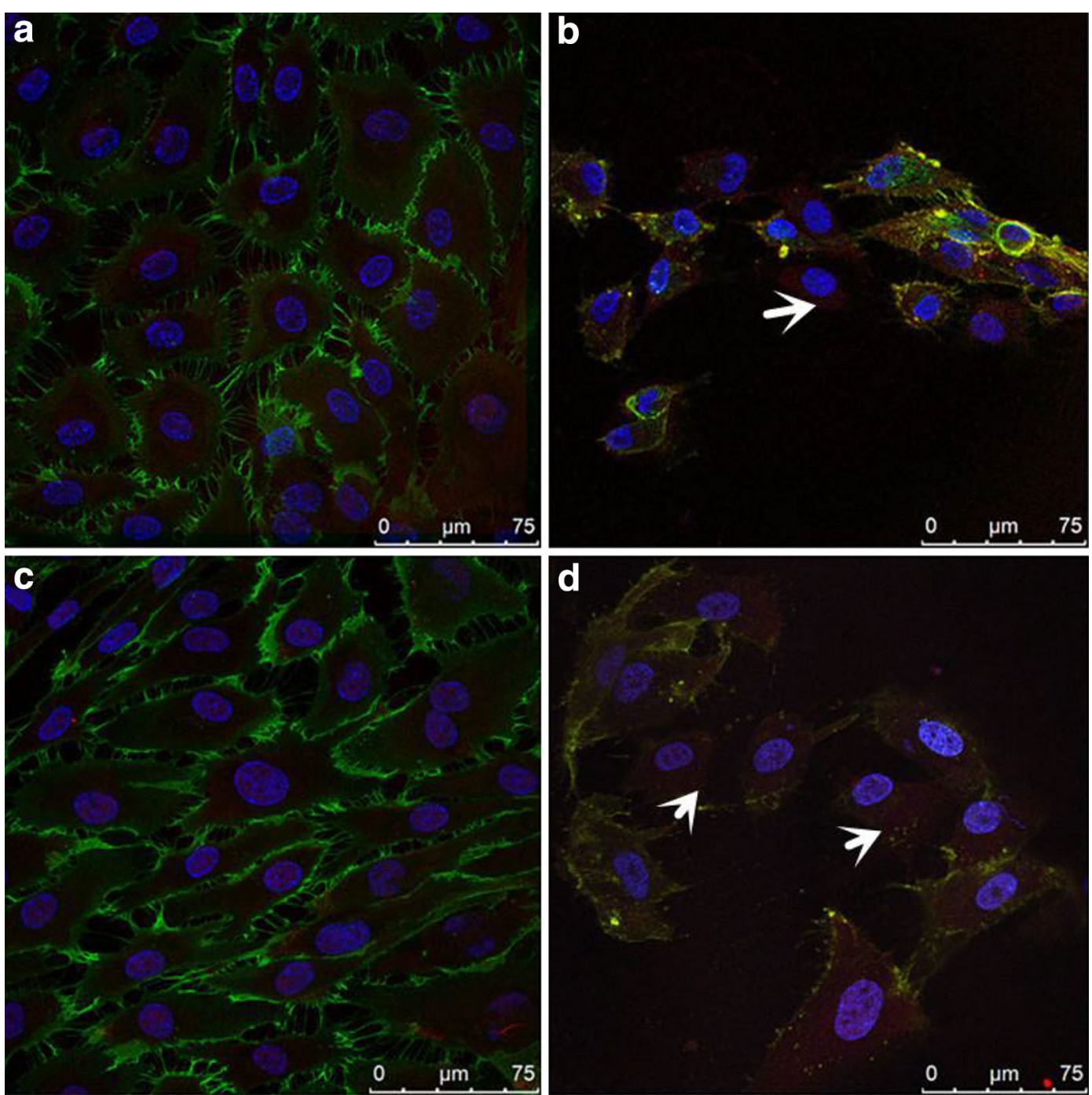

Fig. 5 The influence of high glucose or IL-1 $\beta$ on immunofluorescence of CD31 and FSP1 in HAECs. Representative immunofluorescence images showing CD31 (green), FSP1 (red) labeling and DAPI (blue) stains nuclei. a Normal ECs monolayers displayed a cobble stone morphology. b A merge of the three images revealed some cells populations that acquired a spindle-shaped morphology and lost CD31 expression (white arrow). c HAECS exposure to IL-1 $\beta$ alone for $48 \mathrm{~h}$ acquired a spindle-shaped morphology. $\mathbf{d}$ High glucose and IL-1 $\beta$ in combination resulted in decreased CD31 (the left white arrow) and increased FSP1staining (the right arrow). a normal glucose (5.5 mM) group, b high glucose (30 mM) group for 48 h; c treatment with a normal glucose $(5.5 \mathrm{mM})+\mathrm{IL}-1 \beta(10 \mathrm{ng} / \mathrm{ml})$ treatment for $48 \mathrm{~h}$, d treatment with a high glucose $(30 \mathrm{mM})+\mathrm{lL}-1 \beta(10 \mathrm{ng} / \mathrm{ml})$ treatment for 48 h. Scale bar, $75 \mu \mathrm{m}$ 


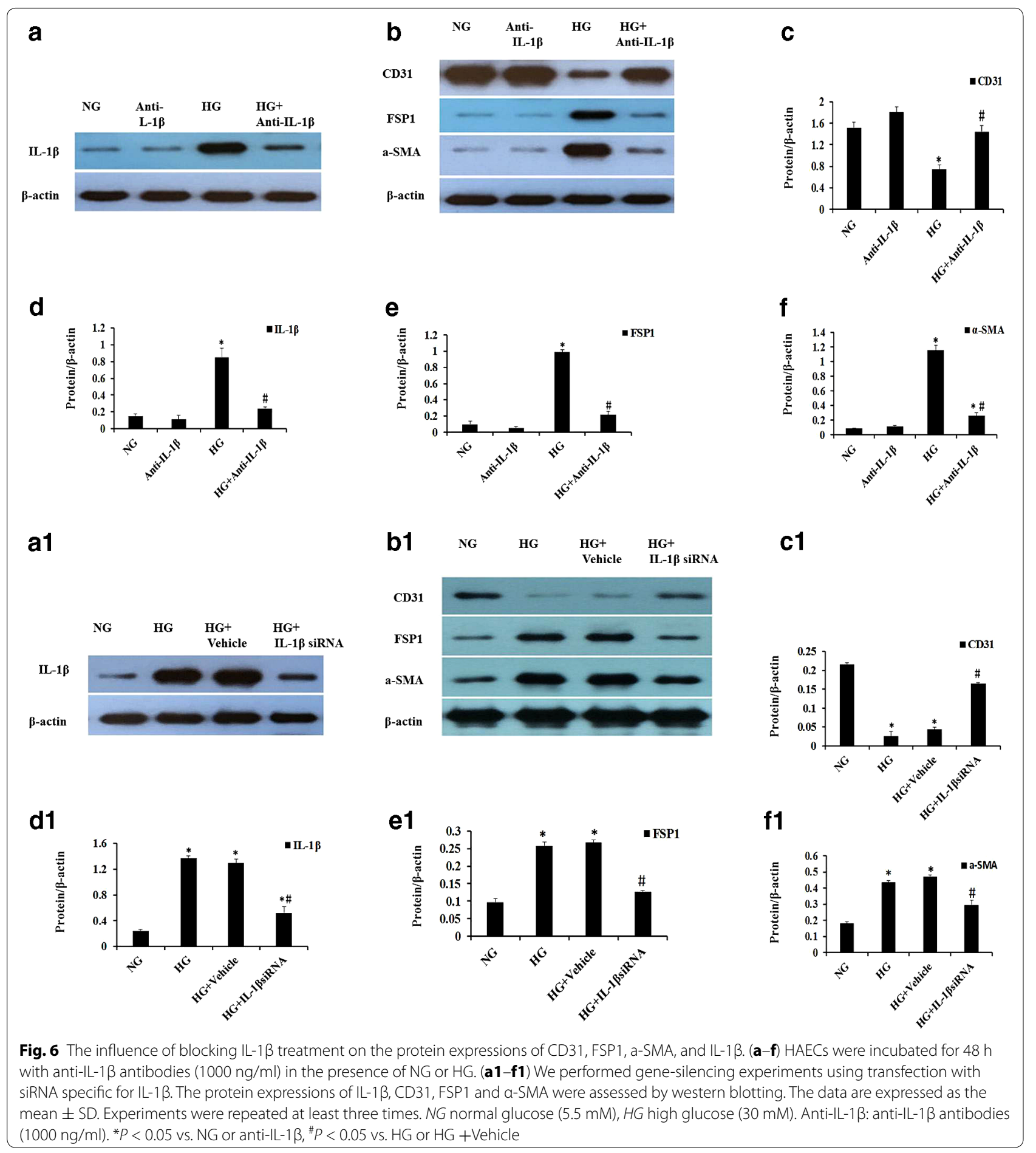

heads), which suggested that phenotypic transition occurred in HAECs.

Parallel with the findings above, electron microscopy analysis of the NG group demonstrated that the EC therein exhibited normal structures (Fig. 8a). In contrast, the HG group that was treated with HG
(30 $\mathrm{mM}$ ) for $48 \mathrm{~h}$ exhibited endothelial protrusions, a significantly roughened endoplasmic reticulum, and microfilamentation (Fig. 8b, red arrow head). Interestingly, these changes were attenuated by the treatment with anti-IL1 $\beta$ antibodies (Fig. 7c $P<0.05$ with Fig. 8c). 

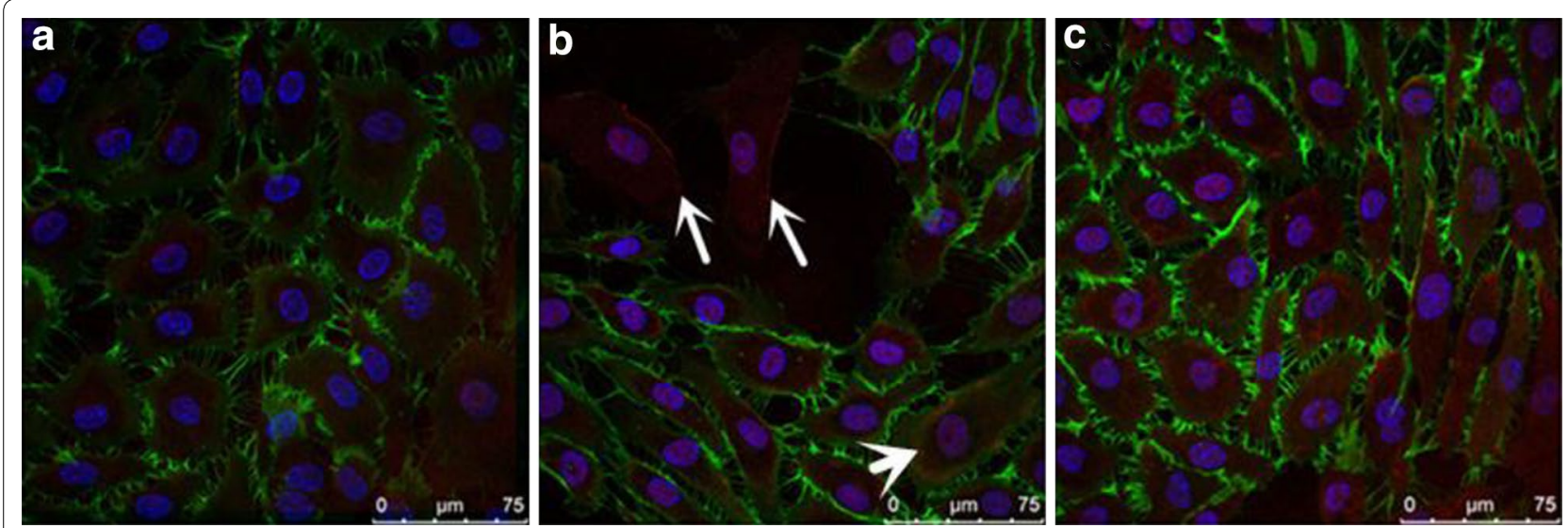

Fig. 7 Anti-IL-1 $\beta$ antibodies treatment inhibited high glucose-induced phenotypic transition of HAECs, asassessed by laser scanning confocal microscopy. Representative immunofluorescence images showing CD31 (green), FSP1 (red) labeling and DAPI (blue) stains nuclei. a Normal ECs monolayers displayed a cobble stone morphology. $\mathbf{b}$ A merge of the three images revealed some cells populations that acquired a spindle-shaped morphology and lost CD31 expression (white arrow heads). $\mathbf{c}$ The administration of anti-IL-1 $\beta$ antibodies treatment caused a reduction of these changes $(P<0.05)$. a normal glucose $(5.5 \mathrm{mM})$ group, b high glucose $(30 \mathrm{mM})$ group for $48 \mathrm{~h}$; $\mathbf{c}$ treatment with a high glucose concentration $(30 \mathrm{mM})+$ anti-IL-1 $\beta$ antibodies $(1000 \mathrm{ng} / \mathrm{ml})$ treatment for $48 \mathrm{~h}$. Experiments were repeated three times. Scale bar, $75 \mu \mathrm{m} .{ }^{*} P<0.05 \mathrm{vs} . \mathrm{HG}$

\section{Discussion}

A hallmark of diabetic vascular pathology is EC damage [26]. EC damage is considered to be the early site, accelerates atherosclerosis and subsequently causes cardiovascular events [27]. The mechanisms behind this phenomenon are probably multifactorial including the polyol pathway, activation of $\mathrm{PKC}$, increased oxidative stress, advanced glycation end (AGE) product formation, and inflammation $[25,28,29]$. Meanwhile, these influencing factors are related to each other, rather than isolated. For instance, the oxidative stress and AGE can result in inflammation [30]. Moreover, recent studies revealed that PKC $\beta$ activation could promote EC inflammation and cause EC damage in diabetes $[28,31,32]$. The inflammation, including cytokines, also plays an important role in EC damage in diabetes.

A large body of evidence emphasized that the lowgrade chronic inflammatory activation, as a potential contributor to EC damage, increased the vascular diseases [33]. Indeed, previous studies suggested that the diabetes was an inflammatory disease, which was mainly based on the increased plasma concentrations of IL-6, IL-1, and TNF- $\alpha[3,11,34]$. And the increased cytokines, serving as early markers for vascular inflammation, could be responsible for EC damage in diabetes [15]. Especially, IL-1 $\beta$, one of the earliest activated cytokines in the injury tissues, was reported to induce EC damage in isolated rat mesenteric micro-vessels [35, 36]. Recent study suggested that EC damage in diabetes might be linked to the mechanisms triggered by IL- $1 \beta$ and recovered by IL-1 receptor antagonist [15]. Moreover, the enhanced expression of IL-1 $\beta$ in HG conditions was described in human monocytes and macrophages [37, 38], pancreatic islets [39], and HAECs [40], meanwhile, the up-regulation of IL-1 $\beta$ was also described in the retina and retinal vessels from diabetic rats [10]. In the present study, we demonstrated that HG induced IL- $1 \beta$ expression, which was consistent with the observation by Asakawa et al. [40]. Our findings indicated that IL- $1 \beta$ induced its own synthesis at dose-dependent manner (data not shown), as was known to be the trigger and amplifier of inflammation [10]. These results implied that EC was also a major source of IL-1 $\beta$ under HG conditions. Simultaneously, we observed elevated PKC $\beta$ level accompanied by increased IL-1 $\beta$. Furthermore, the next findings showed that IL-1 $\beta$ production was up-regulated by PMA and down-regulated by $P K C \beta$ inhibitor in HAECs exposed to HG. Therefore, the results indicated that PKC $\beta$ activation may mediate IL-1 $\beta$ production in HAECs with HG exposure. Thus, it seemed plausible that IL- $\beta$ and PKC $\beta$ were involved in HG-induced EC damage. However, the mechanism underlying the effect of IL- $\beta$ on EC damage in diabetic is incompletely understood.

Increasing evidence showed that when exogenous IL-1 $\beta$ stimulated retinal, human intestinal and dermal micro-vascular EC,respectively, EC underwent EndMT $[16-19,41]$. EndMT was first described in the embryonic heart [42], involved in murine transplant arteriopathy, vascular cerebral cavernous malformations and vascular graft remodelling [23, 43, 44]. Our previous work also demonstrated that angiotensin II was partially involved in the process of EndMT, contributing to HG-induced EC damage $[24,25]$. The process could be regulated by multiple factors such as angiotensin II and endothelin-1 under 

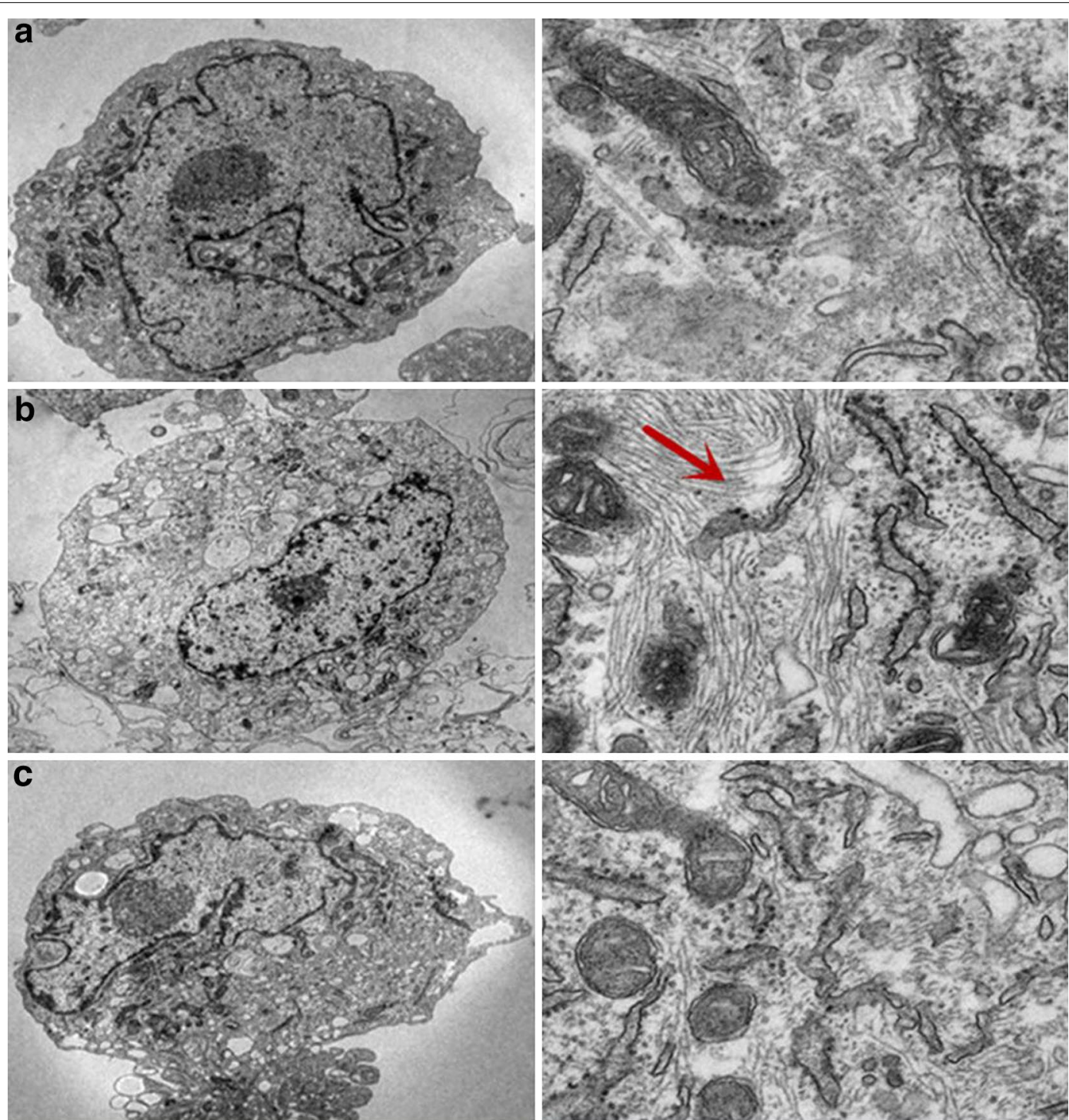

Fig. 8 Anti-IL-1 $\beta$ antibodies inhibited high glucose-induced phenotypic transition of HAECs, as assessed by transmission electron microscopy. Transmission electron microscopy depicts the change in cellular ultrastructure following HG (30 mM) exposure (left magnification $\times 10,000, v s$ right magnification $\times 40,000$ in the same group). a It can be seen that normal HAECs present with few microfilaments and a rough endoplasmic reticulum. b After exposure to $\mathrm{HG}$, microfilamentation and a swollen rough endoplasmic reticulum appeared in the cytoplasm. c These changes were attenuated by treatment with anti-lL-1 $\beta$ antibodies. a normal glucose $(5.5 \mathrm{mM})$ group, b high glucose $(30 \mathrm{mM})$ group for 48 h; c treatment with a high glucose concentration $(30 \mathrm{mM})+$ anti-lL-1 $\beta$ antibodies $(1000 \mathrm{ng} / \mathrm{ml})$ treatment for $48 \mathrm{~h}$

HG conditions. Whether HG-mediated local inflammation, including IL-1 $\beta$, is involved in the mesenchymal phenotype of EC has not been completely elucidated. Our results demonstrated that HAECs, incubated with HG or IL-1 $\beta$, developed a series of phonotypical changes and the over expressions of FSP1 and $\alpha$-SMA, which suggested the occurrence of a phenotypic transition in HAECs. Additionally, HG and IL- $1 \beta$ synergistically resulted in profound similar changes. Moreover, changes above were attenuated by the treatment of anti-IL-1 $\beta$ antibodies or IL-1 $\beta$ siRNA. Together with the results of increased IL- $1 \beta$, we believed that IL- $1 \beta$ may mediate the phenotypic transition in HAECs with HG treatment.

However, the inflammation system is far more complex than the IL-1 system and it is expected that other antiinflammatory treatments such as anti-TNF, or in combination, will have additional and complementary effects on diabetic vasculopathy. 


\section{Conclusions}

In summary, our study demonstrated that HG induced phenotypic transition in HAECs, which was mediated in part by the IL- $1 \beta$ production. The blockade of IL- $1 \beta$ production may prevent the phenotypic transition in HAECs exposured to HG. In addition, PKC $\beta$ activation may be responsible for upregulation of IL-1 $\beta$ by HG. Our findings implied that IL- $1 \beta$ or PKC $\beta$ pathway blockade would be a novel and effective strategy to control diabetic vasculopathy.

\section{Abbreviations}

EC: endothelial cell; IL-1 $\beta$ : interleukin-1 $\beta$; NG: normal glucose; HG: high glucose; MN: mannitol; PKC $\beta$ : protein kinase C- $\beta$; HAECs: human aortic endothelial cells; PMA: phorbol12-myristate 13-acetate; LY: LY317615; FSP1: fibroblast-specificprotein 1; a-SMA: a-smooth muscle actin; siRNA: small interferingRNA; EndMT: endothelial-to-mesenchymal transition; ELISA: enzyme linked immuno-sorbent assay; TEM: transmission electron microscopy.

\section{Authors' contributions}

ZD performed the experiments, analyzed data, interpreted results, and wrote the manuscript. TR contributed equally to this study. WY participated in the HAECs culture and analysis. LL carried out the RT-PCR and Western blotting. LH helped to carry out the immunofluorescent staining. MK and ZX coordinated the study and were involved in the data interpretation. LB participated in the study design and results interpretation and manuscript writing. All authors read and approved the final manuscript.

\section{Acknowledgements}

These studies were supported by grants from the National Natural Science Foundation of China (No.81370919,No.31571186, No.81470997, 81130010).

\section{Competing interests}

The authors declare that they have no competing interests.

Received: 2 December 2015 Accepted: 19 February 2016

Published online: 05 March 2016

\section{References}

1. Liu M, Xiang G, Lu J, Xiang L, Dong J, Mei W. TRAIL protects against endothelium injury in diabetes via Akt-eNOS signaling. Atherosclerosis. 2014:237:718-24.

2. Gilbert RE. Endothelial loss and repair in the vascular complications of diabetes: pathogenetic mechanisms and therapeutic implications mechanisms and therapeutic implications. Circ J. 2013;77:849-56.

3. van den Oever IA, Raterman HG, Nurmohamed MT, Simsek S. Endothelial dysfunction, inflammation, and apoptosis in diabetes mellitus. Mediators Inflamm. 2010;2010:792393.

4. Mudaliar H, Pollock C, Ma J, Wu H, Chadban S, Panchapakesan U. The role of TLR2 and 4-mediated inflammatory pathways in endothelial cells exposed to high glucose. PLoS One. 2014;9:e108844.

5. Shao Y, Cheng Z, Li X, Chernaya V, Wang H, Yang XF. Immunosuppressive/ anti-inflammatory cytokines directly and indirectly inhibit endothelial dysfunction-a novel mechanism for maintaining vascular function. J Hematol Oncol. 2014;7:80

6. Aroor AR, McKarns S, Demarco VG, Jia G, Sowers JR. Maladaptive immune and inflammatory pathways lead to cardiovascular insulin resistance. Metabolism. 2013;62:1543-52.

7. Sena CM, Pereira AM, Seiça R. Endothelial dysfunction- a major mediator of diabetic vascular disease. Biochim Biophys Acta. 2013;1832:2216-31.

8. Dinarello CA, Donath MY, Mandrup-Poulsen T. Role of IL-1 beta in type 2 diabetes. Curr Opin Endocrinol Diab Obes. 2010;17:314-21.
9. Sumpter KM, Adhikari S, Grishman EK, White PC. Preliminary studies related to anti-interleukin-1 $\beta$ therapy in children with newly diagnosed type 1 diabetes. Pediatr Diab. 2011;12:656-67.

10. Liu Y, Costa MB, Gerhardinger C. IL-1 $\beta$ is upregulated in the diabetic retina and retinal vessels: cell-specific effect of high glucose and IL-1ßautostimulation. PLoS One. 2012;7:e 36949.

11. Zhao G, Dharmadhikari G, Maedler K, Meyer-Hermann M. Possible role of interleukin-1 $\beta$ in type 2 diabetes onset and implications for anti-inflammatory therapy strategies. PloS Comput Biol. 2014;10:e1003798.

12. Cavelti-Weder C, Babians-Brunner A, Keller C, Stahel MA, Kurz-Levin M, Zayed H, Solinger AM, Mandrup-Poulsen T, Dinarello CA, Donath MY. Effects of gevokizumab on glycemia and inflammatory marker in type 2 diabetes. Diab Care. 2012;35:1654-62.

13. Liu Z, Zhao N, Zhu H, Zhu S, Pan S, Xu J, Zhang X, Zhang Y, Wang J. Circulating interleukin-1 $\beta$ promotes endoplasmic reticulum stress-induced myocytes apoptosis in diabetic cardiomyopathy via interleukin-1 receptor associated kinase-2. Cardiovasc Diabetol. 2015;14:125.

14. Herder C, Dalmas E, Böni-Schnetzler M, Donath MY. The IL-1 pathway in type 2 diabetes and cardiovascular complications. Trends Endocrinol Metab. 2015;26:551-63.

15. Vallejo S, Palacios E, Romacho T, Villalobos L, Peiró C, Sánchez-Ferrer CF. The interleukin-1 receptor antagonist anakinra improves endothelial dysfunction in streptozotocin-induced diabetic rats. Cardiovasc Diabetol. 2014;13:158.

16. Nie L, Lyros O, Medda R, Jovanovic N, Schmidt JL, Otterson MF, Johnson CP, Behmaram B, Shaker R, Rafiee P. Endothelial-mesenchymal transition in normal human esophageal endothelial cells cocultured with esophageal adenocarcinoma cells: role of IL-1 $\beta$ and TGF- $\beta 2$. Am J Physiol Cell Physiol. 2014;307:C859-77.

17. Maleszewska M, Moonen JR, Huijkman N, van de Sluis B, Krenning G, Harmsen MC. IL-1 $\beta$ and TGF- $\beta 2$ synergistically induce endothelial to mesenchymal transition in an NF-kB-dependent manner. Immunobiology. 2013;218:443-54

18. Wang J, Fan TJ, Yang XX, Chang SM. Transforming growth factor-2 induces morphological alteration of human corneal endothelial cells. Int J Ophthalmol. 2014;7:759-63.

19. Rieder F, Kessler SP, West GA, Bhilocha S, de la Motte C, Sadler TM, Gopalan B, Stylianou E, Fiocchi C. Inflammation-induced endothelial-tomesenchymal transition: a novel mechanism of intestinal fibrosis. Am J Pathol. 2011;179:2660-73.

20. Moonen JR, Lee ES, Schmidt M, Maleszewska M, Koerts JA, Brouwer LA, van Kooten TG, van Luyn MJ, Zeebregts CJ, Krenning G, Harmsen M. Endothelial-to-mesenchymal transition contributes to fibro-proliferative vascular disease and is modulated by fluid shear stress. Cardiovasc Res. 2015;108:377-86.

21. Good RB, Gilbane AJ, Trinder SL, Denton CP, Coghlan G, Abraham DJ, Holmes AM. Endothelial to mesenchymal transition contributes to endothelial dysfunction in pulmonary arterial hypertension. Am J Pathol. 2015;185:1850-8

22. Jimenez SA. Role of endothelial to mesenchymal transition in the pathogenesis of the vascular alterations in systemic sclerosis. ISRN Rheumatol. 2013;2013:835948.

23. Cooley BC, Nevado J, Mellad J, Yang D, St Hilaire C, Negro A, Fang F, Chen G, San H, Walts AD, Schwartzbeck RL, Taylor B, Lanzer JD, Wragg A, Elagha A, Beltran LE, Berry C, Feil R, Virmani R, Ladich E, Kovacic JC, Boehm M. TGF-ß signaling mediates endothelial-to-mesenchymal transition (EndMT) during vein graft remodeling. Sci Transl Med. 2014;6:227-34.

24. Tang R, Gao M, Wu M, Liu H, Zhang X, Liu B. High glucose mediates endothelial-to-chondrocyte transition in human aortic endothelial cells. Cardiovasc Diabetol. 2012;11:113.

25. Tang R, Li Q, Lv L, Dai H, Zheng M, Ma K, Liu B. Angiotensin II mediates the high-glucose-induced endothelial-to-mesenchymal transition in human aortic endothelial cells. Cardiovasc Diabetol. 2010;9:31.

26. Altabas V. Diabetes, endothelial dysfunction, and vascular Repair: what should a diabetologist keep his eye on? Int J Endocrinol. 2015;2015:848272.

27. Vanhoutte PM. Endothelial dysfunction: the first step toward coronary arteriosclerosis. Circ J. 2009;73:595-601.

28. Tabit CE, Shenouda SM, Holbrook M, Fetterman JL, Kiani S, Frame AA, Kluge MA, Held A, Dohadwala MM, Gokce N, Farb MG, Rosenzweig J, Ruderman N, Vita JA, Hamburg NM. Protein kinase C- $\beta$ contributes to 
impaired endothelial insulin signaling in humans with diabetes mellitus. Circulation. 2013;127:86-95.

29. Roberts AC, Porter KE. Cellular and molecular mechanisms of endothelial dysfunction in diabetes. Diab Vasc Dis Res. 2013;10:472-82.

30. Rajamani U, Jialal I. Hyperglycemia induces toll-like receptor-2 and -4 expression and activity in human microvascular retinal endothelial cells: implications for diabetic retinopathy. J Diab Res. 2014;2014:790902.

31. Geraldes P, King GL. Activation of protein kinase $C$ isoforms and its impact on diabetic complications. Circ Res. 2010;106:1319-31.

32. Durpès MC, Morin C, Paquin-Veillet J, Beland R, Paré M, Guimond MO, Rekhter M, King GL, Geraldes P. PKC- $\beta$ activation inhibits IL-18-binding protein causing endothelial dysfunction and diabetic atherosclerosis. Cardiovasc Res. 2015;106:303-13.

33. Wu J, Xia S, Kalionis B, Wan W, Sun T. The role of oxidative stress and inflammation in cardiovascular aging. Biomed Res Int. 2014;2014:615312.

34. Tan H, Wang W, Yin X, Li Y, Yin R. Identification of a selective glucocorticoid receptor ligand for the treatment of chronic inflammation in type 2 diabetes mellitus. Exp Ther Med. 2014;8:1111-4.

35. Shashkin PN, Jain N, Miller YI, Rissing BA, Huo Y, Keller SR, Vandenhoff GE, Nadler JL, McIntyre TM. Insulin and glucose play a role in foam cell formation and function. Cardiovasc Diabetol. 2006;5:13.

36. Vila E, Salaices M. Cytokines and vascular reactivity in resistance arteries. Am J Physiol Heart Circ Physiol. 2005;288:H1016-21.

37. Jiménez-Altayó F, Briones AM, Giraldo J, Planas AM, Salaices M, Vila E. Increased superoxide anion production by interleukin-1 beta impairs nitric oxide-mediated relaxation. J Pharmacol Exp Ther. 2006;316:42-52.
38. Dasu MR, Devaraj S, Jialal I. High glucose induces IL-1 beta expression in human monocytes: mechanistic insights. Am J Physiol Endocrinol Metab. 2007;293:E337-46.

39. Bujak M, Dobaczewski M, Chatila K, Mendoza LH, Li N, Reddy A, Frangogiannis NG. Interleukin-1 receptor type I signaling critically regulates infarct healing and cardiac remodeling. Am J Pathol. 2008;173:57-67.

40. Asakawa H, Miyagawa J, Hanafusa T, Kuwajima M, Matsuzawa Y. High glucose and hyperosmolarity increase secretion of interleukin-1 beta in cultured human aortic endothelial cells. J Diab Comp. 1997;11:176-9.

41. Chaudhuri V, Zhou L, Karasek M. Inflammatory cytokines induce the transformation of human dermal microvascular endothelial cells into myofibroblasts: a potential role in skin fibrogenesis. J Cutan Pathol. 2007;34:146-53.

42. Markwald RR, Fitzharris TP, Manasek FJ. Structural development of endocardial cushions. Am J Anat. 1977;148:85-119.

43. Chen PY, Qin L, Barnes C, Charisse K, Yi T, Zhang X, Ali R, Medina PP, Yu J, Slack FJ, Anderson DG, Kotelianski V, Wang F, Tellides G, Simons M. FGF regulates TGF- $\beta$ signalingand endothelial-to-mesenchymal transitionvia control of let-7 miRNA expression. Cell Rep. 2012;2:1684-96.

44. Maddaluno L, Rudini N, Cuttano R, Bravi L, Giampietro C, Corada M, Ferrarini L, Orsenigo F, Papa E, Boulday G, Tournier-Lasserve E, Chapon F, Richichi C, Retta SF, Lampugnani MG, Dejana E. EndMT contributes to the onset and progression of cerebral cavernous malformations. Nature. 2013:498:492-6.

\section{Submit your next manuscript to BioMed Central and we will help you at every step:}

- We accept pre-submission inquiries

- Our selector tool helps you to find the most relevant journal

- We provide round the clock customer support

- Convenient online submission

- Thorough peer review

- Inclusion in PubMed and all major indexing services

- Maximum visibility for your research

Submit your manuscript at www.biomedcentral.com/submit

() Biomed Central 